\title{
ESTIMATING POLLUTANT REMOVAL REQUIREMENTS FOR LANDFILLS IN THE UK: I. BENCHMARK STUDY AND CHARACTERISTICS OF WASTE TREATMENT TECHNOLOGIES
}

\author{
D. H. Hall ${ }^{1}$, D. Drury ${ }^{1}$, J. R. Gronow ${ }^{2}$, A. Rosevear ${ }^{3}$, S. J. T. Pollard ${ }^{2}$ and R. Smith²*
}

\begin{abstract}
${ }^{1}$ Golder Associates (UK) Ltd., Attenborough House, Browns Lane Business Park, Stanton-on-theWolds, Nottingham, NG12 5BL, UK

${ }^{2}$ Integrated Waste Management Centre, Sustainable Systems Department, School of Applied Sciences, Cranfield University, MK43 0AL, UK

${ }^{3}$ Environment Agency, Kings Meadow House, Kings Meadow Road, Reading, RG1 8DQ, UK.

${ }^{*}$ Corresponding author Tel +44 (0)1234 754963; Fax +44 (0)1234 376171; e-mail r.smith1@cranfield.ac.uk
\end{abstract}

\begin{abstract}
Introduction of the EU Landfill Directive is having a significant impact on waste management in the UK and in other member states that have relied on landfilling. This paper considers the length of the aftercare period required by the municipal solid waste streams that the UK will most probably generate following implementation of the Landfill Directive. Data were derived from literature to identify properties of residues from the most likely treatment processes and the probable management times these residues will require within the landfill environment were then modelled. Results suggest that for chloride the relevant water quality standard ( $250 \mathrm{mg}$
\end{abstract}


$\left.\mathrm{l}^{-1}\right)$ will be achieved with a management period of 40 years and for lead $\left(0.1 \mathrm{mg} \mathrm{l}^{-1}\right)$, 240 years. This has considerable implications for the sustainability of landfill and suggests that current timescales for aftercare of landfills may be inadequate.

Keywords: Equilibrium; completion; emissions; MSW

\section{INTRODUCTION}

In this work, presented here as the first of a series of three companion papers, we consider that landfill pollutant removal requirements are intrinsically linked to the concept of environmental equilibrium. Equilibrium is defined here as that state when emissions from a landfill site occur at a rate that allows sufficient natural attenuation in the surrounding environment to prevent environmental harm, so management is no longer required. To embody the principles of sustainability, equilibrium can only be achieved when the management period (post-closure when the site has ceased accepting waste for disposal, alternatively known as the aftercare period) is measured in decades rather than centuries. Throughout aftercare, the landfill licence or permit holder is required to take active measures to control pollution from the site. This involves monitoring, ensuring integrity of management and engineering systems such as leachate, landfill gas and restoration, and if necessary, taking corrective action until such time as licence or permit surrender is accepted by the regulator. In the UK, the Pollution Prevention Control (PPC) regime [1] requires an estimate of the time taken for a landfill to achieve completion, but guidance is lacking. 
When assessing equilibrium there are a number of issues that must be considered. Firstly, it is expected that landfill liner performance will diminish with time and therefore the rate of leachate or gas leakage may increase. Secondly long-term hydraulic performance of a landfill is dependent on the management and control of leachate levels. If a landfill operator ceases to manage their liabilities, financial provisions allow the regulatory authorities to take over management of the site. Financial provision is usually restricted to a 30-60 year period.

The setting of biodegradable municipal waste (BMW) diversion targets in the EU Landfill Directive [2] and the need to pre-treat waste prior to landfilling is bringing about considerable changes to the composition of wastes going to landfill. There are concerns relating to the sustainability of landfill in general and there is a growing recognition of the long timescales required to achieve equilibrium status; there is a possibility that the change in the nature of waste going to landfill may exacerbate this problem.

In the current study, treated wastes going to landfill were assessed using the number of years to achieve equilibrium status. A current-day landfill, designed and operated largely in compliance with today's UK guidelines was used as the benchmark. We have reviewed residue flows that can be anticipated from various waste pre-treatment and treatment processes with the aim of determining the revised properties of the waste residues that are destined for landfill. Factors that affect the biodegradable content, particle size or density of the material, or lead to the removal of metals etc. could influence the behaviour, both biological and chemical, of waste residues to an extent that landfill management options might not be the same (or even appropriate) for all waste streams. Ultimately, the success or otherwise of the options studied depend on both 
time and cost to achieve equilibrium status. Those techniques or combinations of technology and landfill management that can approach the definition of equilibrium were identified, and the ability to operate the scheme within the current legislative constraints considered. The waste processes investigated are shown in Table 1 as variants of mechanical biological treatment (MBT), refuse derived fuel (RDF) and energy from waste (EfW).

This study has, as a consequence of data shortages, concentrated primarily on the inorganic components of leachate. Beyond understanding the origins of these compounds, little is known of their mass balance through various waste treatment processes. Data relating to the elemental composition of MSW is available for the primary fractions (i.e. paper, plastic, textiles, etc.) but we found few data indicating the elemental analyses of the various residues of treatment processes. Leachate data provide a means of integrating over a large mass of waste, but provide little insight into the total contaminant mass present where solubility limitations restrict the concentrations of some metals.

\section{BENCHMARK STUDY: LEACHATE MODELLING}

To provide a benchmark for the comparison of results from this study, leachate modelling was undertaken to determine the equilibrium status of a typical UK landfill designed and operated on a pre-Landfill Directive basis. The basic scenario was similar to that used for the modelling undertaken to support the definition of European Waste Acceptance Criteria [3] and for this we utilised a published source term model $[3,4]$. Figure 1 shows the basic hydrogeological scenario that forms the basis of the calculations.

The software used for this work was GoldSim [5], which has a probabilistic visual spreadsheet platform capable of transient modelling. Modifications were made to the basic 
scenarios in the GoldSim model used for the UK contributions to the setting of the leaching limit values given in the EU Decision [6] establishing criteria and procedures for the acceptance of waste at landfills. These modifications were carried out to reflect the work contained in the latest release of LandSim 2.5 [7]. They included the gradual unavoidable degradation of the liner and cap (assuming HDPE construction) and the option to simulate the end of managed control (e.g. removing all management controls of leachate levels, recirculation and removal).

In order to provide a framework for the assessment, values were calculated for each species for which a leaching limit value was given in the EU Decision [8] and additionally for ammonium. The point of compliance for the species was the base of the unsaturated zone for List I substances [9], the edge of the landfill for List II substances and a point $200 \mathrm{~m}$ from the site boundary for highly mobile List II and non-listed substances. For each, a water quality standard or guideline was applied. These were either the relevant EU drinking water standard [10] or, where not available, the World Health Organisation drinking water guideline [11]. Also used was a kappa value for each species that served to describe the rate of concentration decline, and an appropriate individual contaminant/subsoil interaction $\left(\mathrm{K}_{\mathrm{d}}\right)$ value for the liner and geosphere. Information about kappa and $\mathrm{K}_{\mathrm{d}}$ values was taken from Hjelmar et al. (2001).

The model was run to determine the end of the aftercare period, i.e. when groundwater quality at the relevant point of compliance remained below the relevant water quality standard or guideline. This is a challenging modelling exercise, as emissions from the landfill are dynamic and need to be below certain emission criteria prior to the management system being switched off. The result of removal of management control will be an increase in leachate levels and a comparable 
increase in leakage rate. Hence, shortly after the removal of management control, there will be a period when the flux of contaminants from the site increases as a result of increased leakage. By treating the period of management control as a variable and running the model with this input represented as a logarithmic uniform probability distribution function varying between 3 and 2000 years, the appropriate time scale was determined for each contaminant.

\section{RESULTS - BENCHMARK STUDY}

The results are shown in Tables 2 and 3, which, with Figures 2 and 3, give an insight into the methodology. Achievement of equilibrium status for conventional landfills is likely to be controlled by a number of key species; chloride, lead, zinc and other metals. That is not to say that these controlling species will remain the same for other landfill types containing residues different from those in a typical current landfill used as the benchmark.

The benchmarking of a standard landfill showed that many of the contaminants achieve equilibrium status, with respect to leakage to groundwater, in a surprisingly short period. In this example, even ammoniacal nitrogen met the criterion within a relatively short period. However, other contaminants, notably lead, took a considerable amount of time to reach stabilisation. The leachate concentrations used as a starting point in this exercise are taken from the geometric mean values within LandSim, which in turn are based on published research [12].

A second scenario was run with the leachate concentrations set to the $\mathrm{C}_{0}$ values prescribed for stable, non reactive hazardous waste going to a non-hazardous landfill. $\mathrm{C}_{0}$ is the initial peak concentration of the contaminant in the leachate $\left(\mathrm{mg} \mathrm{l}^{-1}\right)$ when subject to the standard upflow 
percolation test [13]. Results were significantly different with most species requiring an aftercare period in excess of 1000 years and 50\% requiring a management period of greater than 2000 years (Table 3).

Figure 2 shows the relationship between receptor concentration and management time for chloride for a non-flushing landfill that has accepted predominantly raw MSW. It is clear that the relationship between the length of management time and the reduction of receptor concentrations is not linear.

Each point on the graph is the result of modelling a different management period using a logarithmic sampling scale. The relevant water quality standard (WQS) for chloride is $250 \mathrm{mg} \mathrm{l}^{-1}$ and this was achieved with a management period of 40 years (Table 2). It must be stressed that the leachate chloride concentration at this time (i.e. $1275 \mathrm{mg} \mathrm{l}^{-1}$ at 40 years) would not meet the WQS. However, the processes of natural attenuation and dilution result in compliance if the management of leachate ceases at this time. It must also be stressed that on the cessation of leachate management there is an expectation that leachate treatment (or removal) ceases, leachate levels will rise, and leakage will increase in line with the increased leachate head. Furthermore, it should be noted that the concentration at the receptor did not reach $250 \mathrm{mg} \mathrm{l}^{-1}$ at 40 years. This maximum concentration occurred at 156 years, some 116 years after the management of the site ceased.

Figure 3 shows a similar relationship for lead. In this case, the aftercare period required to reach equilibrium status was approximately 400 years (Table 2). The leachate concentration at this time was $0.12 \mathrm{mg} \mathrm{l}^{-1}$ (twelve times the WQS). The actual time taken for the maximum groundwater concentration to be realised was 4000 years. There is therefore a large disjoint between the time 
when management of leachate could cease and the time when the maximum concentrations in groundwater will be realised.

\section{NATURE AND CHARACTERISTICS OF TREATMENT TECHNOLOGY RESIDUES}

Almost all municipal waste authorities in the UK are involved with a certain amount of pretreatment of MSW in the form of separate collection of some recyclables direct from households or from collection points. Some have increased this basic minimum diversion from landfill with the addition of materials recycling facilities (MRF) for more efficient removal of recyclables, or the provision of thermal and biological treatment facilities intended to be significant alternatives to landfill such as incineration or composting. For this study a number of representative treatment options were selected and the effect of these on the timescale for management of the landfilled residues was assessed.

Experience has shown that to achieve BMW reduction rates as high as those set by the Landfill Directive requires more than simply providing separate collection of recyclables [14]. Inevitably, therefore, the residues that will be landfilled in the future will be from a series of technologies and processes. In terms of process flows or combinations of the different technologies, a number of recent developments in the UK were reviewed and some UK disposal authorities' early waste strategies were studied to determine the most likely scenarios.

Waste sorting splits raw MSW into several waste streams; some of which are typically suitable for recycling. For the purposes of this study, waste sorting was reviewed as an integral 
part of the wider treatment process, rather than as a stand-alone technology. Consequently, little attempt was made to analyse the potential affects of residues obtained solely from waste sorting.

\section{Materials recovery facilities}

Materials Recovery Facilities (MRFs) are becoming more common throughout the UK and it is envisaged that they will remain an integral part of municipal waste recovery processes in the UK. Commonly paper, cardboard, plastics and metals suitable for recycling are derived as marketable bailed materials following sorting and separation during MRF operations. Unsorted residues may be disposed of to landfill. MRFs can be categorised into clean and dirty variants. Clean MRFs process source-segregated material for recovery. Dirty MRFs (Figure 4) are simpler forms of MRF, most of which have now been phased out. Dirty MRFs process the entire collected (unsorted) waste stream.

\section{Mechanical biological treatment}

MBT is a generic term for a range of processes used to treat MSW (normally post source segregation) by means of a combination of mechanical separation and biological treatment. Although different technologies may be used, they have similar characteristics. These commonly comprise three stages: mechanical size reduction, the driving off of moisture and, finally, material separation to segregate output streams for different purposes.

Figure 4 illustrates the fate of each material extracted from the process. In this study, all the systems involving the elementary steps are referred to as MBT. MBT outputs incorporate selected 
recyclable materials and a stabilised waste. Extraction of recyclables occurs both before and after biological processing of the residual waste.

It is widely believed that MBT pre-treatment of waste prior to landfilling reduces landfill emissions compared to untreated MSW. It is, however, difficult to track an accurate mass balance of trace contaminants through the system.

During the process there is a reduction in mass which has been mainly attributed to the decrease in water content and the degradation of organic material. Weight reductions typically range between $20 \%$ and $40 \%$ [15-18]. Volume reductions are thought to be a result of the mechanical stage, e.g. shredding. They are reported to be between $35 \%$ and $79 \%$, largely depending on the degree of landfill diversion during the MBT process. Virtually all plants have means of removing ferrous and non-ferrous metals, and many also attempt to remove a reasonable proportion of the plastics that enter the process.

MBT residues typically achieve a higher emplaced density within landfills than standard MSW. A value of $1.3 \mathrm{t} \mathrm{m}^{3}$ was reported by Binner [19]. Scheelhaase and Bidlingmaier [20] found during lysimeter tests that storage densities of $1.6 \mathrm{t} \mathrm{m}^{3}$ were achievable. They also reported a notable decrease in permeability between feedstocks and MBT residues as a result of the increased density, high homogeneity, smaller grain sizes and the high proportions of 'earthy' components of the material following MBT procedures. Some authors report hydraulic conductivity ranges from $<1 \times 10^{-10} \mathrm{~m} \mathrm{~s}^{-1}\left(<25 \mathrm{~mm}, 50\right.$ weeks treatment) to $<1 \times 10^{-11} \mathrm{~m} \mathrm{~s}^{-1}$ ( $<12 \mathrm{~mm}, 5$ weeks treatment). However, a more recent report [21] shows the relationship between MBT residue permeability and 
applied load. Results range from $3 \times 10^{-5} \mathrm{~m} \mathrm{~s}^{-1}$ for waste under a load of $50 \mathrm{kN} \mathrm{m}^{2}$ to $6 \times 10^{-9} \mathrm{~m} \mathrm{~s}^{-1}$ with an applied load of $550 \mathrm{kN} \mathrm{m}^{2}$. These values are almost identical to those derived for raw MSW and as such indicate a comparable permeability. Care needs to be taken when comparing the results with raw MSW as the density of the two waste streams will be different.

Comparison of the organic matter content before and after the MBT process (using loss on ignition data) indicates degradation of between 50 and $70 \%$ by weight of organic dried solid matter. It should be noted that the composition of input material is a key-determining factor. Further intensive composting over a protracted period could reduce the weight of organic material (dried solid) to $12 \%$ of the original feedstock but this is unusual and would only result from highly selective waste streams. In most cases the loss on ignition value drops to 25 - $35 \mathrm{wt}$. \% of organic dried solid matter after pre-treatment [20].

Through landfill simulation experiments, the influence of MBT pre-treatment has been compared to MSW in terms of leachate quality [15]. Available data demonstrate that for pre-treated waste the acidic phase (during which high strength leachate is produced from MSW) does not occur. Substantial reductions in long-term concentrations of Chemical Oxygen Demand (COD) and Total Nitrogen (as N) have been reported [22] compared to MSW, although the precise basis of these claims is uncertain. It is clear that leachate strengths are lower, but the composition of the non-degradable (hard) COD is unknown. Data are also available from several small-scale outdoor lysimeters which contained MSW and MBT residual wastes, e.g. Kabbe, 2000, reported in Robinson et al. [18]. Results for heavy metals content from both of these example lysimeters were similar. 
Leaching tests undertaken on samples of MSW and MBT residues, solely for ammonia and TOC have been reported [17]. Concentrations of ammoniacal-N were found to be similar for MSW and Mechanically Sorted Organic Residues (MSOR) of around $500 \mathrm{mg} \mathrm{l}^{-1}$, but were notably lower for MBT waste, at about $150 \mathrm{mg} \mathrm{l}^{-1}[18]$.

The quality of MBT waste materials (and hence landfill leachate quality) will vary as a consequence of the extent of source-separation of the waste inputs (urban or rural source, seasonal collections), type of mechanical pre-treatment and type and duration of biological treatment [23]. Leachate quality data from full-scale landfill sites are also consistent with the loss of the acetogenic state in MBT waste landfills [19]. This is highlighted by comparatively high $\mathrm{pH}$ values during the first few years. Biochemical Oxygen Demand (BOD), COD and ammonium are all reported to be considerably lower in MBT pre-treated waste than in MSW landfills. The concentrations of some heavy metals are also reduced especially zinc, but it is recognised that the solubility of some metals (especially zinc) tend to reduce markedly at the onset of methanogenesis.

For organic compounds (e.g. mecoprop), evidence suggests that effective composting processes are able to reduce the subsequent concentration in the leachate to below those in sites accepting MSW and MSOR. In practice, the extent of removal of mecoprop from leachates may be a good surrogate measure of the efficiency of the composting process itself, to which waste fractions have been subjected. It is noted however that the degree of composting achieved and the efficiency of individual composting processes cannot be determined by the duration of composting. A further leachate quality summary for leachates from landfills/test cells containing untreated MSOR and MSOR subjected to various composting regimes was obtained from Bone et al. [23]. 
Robinson et al. report a suggested leachate source term for landfills accepting predominantly MBT residues [18]. This represented their best estimate based on an extensive desk study and independent sampling from a number of European landfill sites.

\section{MBT/composting}

Many MBT systems were originally developed as compost plants. The intention was to convert raw MSW into quality compost, but there are few examples where the product has achieved the necessary quality, and large quantities are landfilled. The quality of the compost derived from MBT systems varies considerably and is largely dependent upon the quality of input material and process retention period. While the residue has been "composted" in the process, it still contains some of the contaminants present in the feedstock. The suitability of the resultant material for beneficial application is generally limited to low grade uses such as landfill daily cover, 'brownfield' restoration or forestry.

In the context of MSW in the UK, the term composting has usually been taken to mean the green waste shredding and outdoor windrowing that is undertaken by many municipal authorities. This study assumed that no significant residue from this process would be sent to landfill.

Changes in the composition of the organic fraction of municipal solid waste during the biodegradation process and the final waste products are strictly dependent on the process conditions. The reduction of carbon content due to biodegradation increases with process temperature from $20 \%$ at $20^{\circ} \mathrm{C}$ to about $40 \%$ at $37^{\circ}-42^{\circ} \mathrm{C}$ [24]. The fate of heavy metals and non- 
degradable species is less certain and they are likely to be unaffected by the process. However, with the volume and mass reduction of the waste the concentration (but not the mass) of these contaminants is likely to increase.

Organic trace contaminants in conventional MSW include a number of species that are resistant to biodegradation in the anaerobic conditions that quickly become established in a modern MSW landfill. Species such as mecoprop, toluene and benzene do not undergo significant anaerobic degradation. While volatile species (such as the BTEX compounds) leave the landfill via landfill gas and may be destroyed within combustion plant, non-volatile species such as mecoprop will only be removed by leaching. The removal of these species via aerobic degradation within the composting process is beneficial, should the material be landfilled.

\section{MBT/Anaerobic digestion}

The digestion of MSW is not common in the UK. The success of anaerobic digestion of MSW depends upon a high degree of pre-sorting and mechanical separation. Anaerobic digestion reduces organic waste to a relatively stable solid residue similar to compost. The process can be completed in 2-3 weeks. There is the risk that the digestate will contain high proportions of heavy metals, particularly when treating unsorted waste as demonstrated in Table 4 . Anticipating this, it is necessary to carefully oversee the feedstock going to the reactor. The main products from AD are biogas, a liquid fraction and a solid residue. No data could be obtained on the mass balance of contaminants. 
Leachate quality data for landfills accepting AD residues are poorly documented. However, it is anticipated that leachates from those residues that have not been subjected to a post composting stage will be of a similar quality to a methanogenic leachate from a typical MSW site containing moderate levels of ammonia, residual hard COD, chloride concentrations comparable with MSW and the range of heavy metals typically found in MSW leachate.

For those sites that accept AD residues that have been composted following the AD stage, leachates are likely to be similar to leachates derived from MBT composted waste that is landfilled. Leachate concentrations from one site that had accepted AD composted material are taken from Robinson et al. [18]. The leachate was very similar to a methanogenic leachate albeit that the ammoniacal $\mathrm{N}$ concentration was less than $200 \mathrm{mg} \mathrm{l}^{-1}$. There was a low, but detectable, concentration $\left(0.47 \mu \mathrm{g} \mathrm{l}^{-1}\right)$ of mecoprop although there was a near absence of other identifiable trace organic contaminants.

\section{Refuse derived fuel (RDF)}

RDF (alternatively known as solid recovered fuel or SRF) has different meanings in different member states of the EU. It is well-established in Austria, Finland, Germany, Italy, the Netherlands and Sweden whilst in Belgium and the UK RDF production is still developing [25]. RDF generally encompasses a residue that is produced from waste with the intent of being traded and co-burnt in installations for power generation or in a manufacturing process where heat is required (e.g. cement production). The principal purpose for developing RDF from MSW is to arrive at a dry, high-calorific value (15->18 MJ/ kg [26]) product of improved homogeneity compared with raw MSW. In some cases, purpose-built incinerators have been developed to receive only RDF from 
MSW. The European standards organization (CEN) is classifying fuel according to net calorific value, chlorine and mercury content . However, the particle size, moisture content and fuel composition are also important.

There is a high likelihood that not all RDF will be utilised continuously in co-incineration plants. Historically, considerable amounts of RDF have been stored or landfilled for a variety of reasons such as lack of demand or poor quality. Hence, this study considered that one potential process flow will result in RDF being landfilled directly.

The composition of RDF from MSW will vary according to the origin of waste material and the sorting/separation process. This will in turn greatly influence the properties of RDF such as the calorific value. A typical composition for RDF from MSW originating from the UK is plastic (20\%), paper/cardboard (58\%), wood (5\%), textile (15\%), non-combustibles e.g. glass and metals (2\%) [26].

The important characteristics for RDF as a fuel are the calorific value (20-23 MJ/kg for source-separated MSW; 13 MJ/kg for mixed MSW), water (10-35\%), ash (10-16\%), sulphur (0.2\%) and chlorine $(0.3-0.7 \%)$ contents [25]. These values are indicative and also vary according to the sources, the collection system (mixed or source separated) and the treatment applied (screening, sorting, grinding, drying etc.) [25]. RDF tends to affect the concentrations of cadmium, lead, copper and zinc when co-incinerated with other material. No specific information could be obtained on leachate quality from landfilling 100\% RDF incineration residues. 
Wet flock-type RDF is prepared by shredding, screening, magnetic separation, eddy current separation and possibly air classification to remove the non-combustible fraction (e.g. ferrous materials, glass and grit). The output tends to be dry and odour-free, with an enhanced calorific value, as both the moisture content and non-combustible fraction have been substantially reduced.

No specific information could be obtained from RDF/MBT where RDF results from a more sophisticated MBT process. However, if the material is incinerated, it is unlikely to differ significantly from RDF ash. If, because of lack of markets, it is not burnt, then it is likely to be similar to MBT residues that have been sent to landfill.

\section{Mass burn incineration}

In mass burn incineration the volume of waste is reduced by $90 \%$ and its weight by $75 \%$ [27]. Generally up to three different types of waste are produced: bottom ash, fly ash and air pollution control (APC) residues. Bottom ash arises from high temperature oxidative processes acting on the waste. Fly ash is the fine particulate matter (typically 1 to $500 \mu \mathrm{m}$ ) which is carried over from the combustion chamber and can be collected separately from other air pollution control residues. APC residues result from the collection of other air pollutants from incinerator flue gases, especially acid gases, volatilised heavy metals and other micro pollutants. The three wastes have different compositions and will produce different emissions when landfilled. Fly ash and APC residues are unlikely to meet the hazardous waste acceptance criteria for acceptance at a landfill site, without treatment. 
The Environment Agency reports that incinerator bottom ash (IBA) is approximately $25 \%$ to $30 \%$ by weight and $10 \%$ by volume of input, and APC residues are approximately $3 \%$ by weight of waste input [28]. These data depend on factors which include quantity, composition of waste burnt, any recycling schemes and the design and operation of the plant. MSW IBA will have a density of about 1.5 tonnes $\mathrm{m}^{3}$.

Chemical analysis and characterisation of bottom ash and APC residues from three UK incinerators has been undertaken [18]. An example of the chemical composition of fresh bottom ash is presented in Polettini et al. [29].

Pre-treatment processes such as carbonation and acid treatment have been demonstrated to influence the $\mathrm{pH}$ of the waste and hence affect the waste emissions (via leachate). Williams [30] presented typical composition of bottom ash, fly ash, and APC residues from a dry/semi-dry system and a wet control system.

For leachate produced from incinerator bottom ash and APC residues, Robinson et al. [18] reported that the trace elements and some of the major ions in leachates are strongly influenced by several chemical, and occasionally biological reactions that begin as soon as the ash reaches the quench tank and continue, often for many decades, within the landfill. They reported that variations in ash leachates are more likely to occur as a result of site topography and water regime than any variation in reactions occurring after landfilling. Leaching test data are therefore valued as a good guide to actual leaching quality. Concentration ranges for maximum levels 
observed in leaching tests on bottom ashes at liquid/solid ratios below 0.5 are provided by Hjelmar [31].

Inorganic components from a lysimeter study of bottom ash leached to a liquid/solid (L/S) ratio of 1.4 have been reported by Stegmann et al. [32]. Throughout this lysimeter study, chloride exhibited a washout pattern, falling to a L/S ratio of $\sim 0.7$, then continued at a lower concentration for the remainder of the experiment. The $\mathrm{pH}$ remained high throughout due to the lime content, although sub-sampling at the end showed that lower $\mathrm{pH}$ values had developed in the upper (exposed) surface, indicating partial carbonation.

Sulphate concentrations were initially low, presumably because of very high calcium concentrations. Sulphate then fell further, before rising during the second half of the study, as carbonation began to remove calcium from solution. This is consistent with a long-term decrease in alkalinity. At the end of the test only $2 \%$ of the sulphate content had been leached.

Leachate quality data are available from a bottom ash landfill in Switzerland [33, 34]. L/S ratios at the time of the study were reported to be $0.2-0.25$. Dry weather concentrations of $\mathrm{Cl}, \mathrm{SO}_{4}$ and Na were consistent with published eluate values for low L/S ratios [31], while Total Organic Carbon (TOC), K, Ca and most of the heavy metals were generally at lower concentrations than indicated in eluate concentrations.

A long-term dataset of leachate quality (1973 to 1998) is available for a PVC lined landfill [3]. The site accepted $\sim 85 \%$ bottom ash and $\sim 15 \%$ fly ash. It was noted by Robinson et al. [18] that 
copper concentrations correlated strongly with dissolved organic carbon (DOC) indicating the presence of strong organic complexes. This is an issue raised by a number of researchers working with IBA leaching studies. It is possible that a number of other metals also exhibit similar relations with DOC, but to a lower degree. The mobility of copper as a complex is likely to be far higher than its mobility as a metal ion and could have implications for groundwater contamination from sites accepting IBA.

Bottom ash, while having virtually no dioxins, contained large numbers of other trace organics including halogenated aliphatic and aromatic hydrocarbons, BTEX compounds, alkenes and PAHs. Concentrations of trace organics were found to vary by up to three orders of magnitude in bottom ash from three different sites [18].

Carbonation is an important process that affects the physical and chemical nature of bottom ashes. It is formed by the reaction of atmospheric carbon dioxide with lime in the wastes, forming calcium carbonate. Carbonation of the bottom ash increases leachate concentrations of calcium and sulphate ions, but has no significant impact on the leaching of most other ions, DOC, organic nitrogen, and trace organics. However, it lowers $\mathrm{pH}$ significantly and the concentrations of certain heavy metals in the leachate by orders of magnitude, while some trace metals increase [18]. Insolubility of lead (in the short-term) can be ensured through accelerated aging of the fly ash by effective contact between wet fly ash and exhaust gas of the incineration plant [35]. 


\section{Fluidised bed incineration}

This type of thermal treatment (a simple modification to mass burn) involves the waste being used as a fuel, suspended by an updraft supply of air, and kept 'fluidised' on a base of small inert particles such as sand or dolomite. Pre-processing essentially involves the removal of large items such as white goods and ferrous and non-ferrous metals and may be extended to include the recovery of other materials such as recyclables. However, it is noted that savings are made when compared with basic incineration systems because of the possibility of including lime in the combustor material to inhibit the production of acid pollutants. Furthermore, there is no need for the expensive bolt-on air pollution control systems typical of mass burn incinerators to clean up the flue gases. Fluidised bed incineration ensures a high level of waste destruction due to both the preparation of the waste and the method of combustion.

The incineration of MSW using a fluidised bed system is best achieved with some form of pre-screening and shredding, or the production of RDF pellets. Fluidised bed incinerators also have the potential for burning organic liquids, acid tars and sludges.

\section{Pyrolysis}

Pyrolysis is the indirect heating of material in the absence of oxygen such that the organic material is gasified and the resultant solid residues are inert and mainly contain carbon. Pyrolysis can be used to treat organic wastes, rendering the residues biologically inert while extracting a fuel as an energy source for later use. Organic waste is transformed to a medium calorific gas, liquid and a char fraction. These contain hydrocarbons (gas and oils/tars) and solid residue (char/pyrolysis coke) containing carbon, ash, glass and non-oxidised metals. The pyrolysis process 
occurs without the release of polluting dust containing dioxins and/or nitrogen oxides (combustible gases are released). These combustible gases can be used in any industrial application requiring heat or energy.

Studies have shown that increasing the temperature of pyrolysis decreases char production and increases oil and water production. Gas production increases between 300 and $420^{\circ} \mathrm{C}$, but then stays constant. For flash pyrolysis at temperatures less than $600^{\circ} \mathrm{C}$, the production of oil is very high; moreover, at temperatures above $700^{\circ} \mathrm{C}$ gas production is very high.

The Plasma Pyrolysis/Vitrification (PP/V) system produces a solid vitrified residue which presents a low leachability of pollutants and low toxicity levels in leachates [36]. A number of waste streams have been processed at the pyrolysis plant in Bristol including a batch of RDF. Subsequent analysis of the ash (char) is shown in Table 5 [37].

\section{Gasification}

Gasification is a similar process to pyrolysis but takes place with the addition of some oxygen as air or steam. The process produces a mixture of combustible gases (primarily methane, complex hydrocarbons, hydrogen and carbon monoxide), ash and a tar. The major environmental benefit of this process is that it retains pollutants (the sulphur, heavy metals etc.) in the ash instead of the gas phase and prevents subsequent discharge to the atmosphere. The emissions from this technology may be lower than produced by conventional incineration and will require less flue gas treatment. There is little data available in the public domain regarding the contaminant 
concentration of the char. Initial indications [37] are that the char may have similar leaching properties to incinerator bottom ash.

\section{CONCLUSIONS}

During the last two decades the estimated timescale for the potential polluting life of a large modern landfill has increased from early estimates of 20-40 years to greater than 500-1000 years. Currently, technical and financial provision for post-closure liabilities is usually made for a 30-60 year period. Modelling results suggest that this period may be inadequate if measures are not taken to increase the rate of waste stabilisation.

Initial benchmark study results for pre-Landfill Directive landfills suggest that two key contaminants (lead and chloride) are likely to control the achievement of equilibrium status. A second scenario run with leachate concentrations set for stable non reactive hazardous waste going to a non-hazardous waste landfill (Landfill Directive) suggests that the post-closure management period is likely to be $>1000$ years for most contaminants with $50 \%$ of contaminants requiring $>2000$ years to achieve equilibrium. The predicted timescales of centuries rather than decades suggest that a reappraisal of the role of accelerated landfill stabilisation techniques such as aerobic and bioreactor landfilling is required. The benchmarking results presented here are a starting point and the next stage was to model the most likely options that may contribute towards meeting the Landfill Directive diversion and pre-treatment targets. This forms a second manuscript that presents the full modelling methodology and results. 


\section{ACKNOWLEDGEMENTS}

This work was jointly funded by the Environment Agency for England and Wales and ESART.

This paper is published with permission. Opinions expressed are the authors' alone.

\section{REFERENCES}

1. Act of Parliament, Pollution Prevention and Control Act 1999. (1999).

2. Council of the European Union, Directive 1999/31/EC on the Landfill of Waste. Official Journal of the European Communities, L 182, 1-19 (1999).

3. Hjelmar O., Van der Sloot H., Guyonnet D., Rietra R.P.J.J., Brun A. and Hall D.H., Development of acceptance criteria for landfilling of waste: an approach based on impact modelling and scenario calculations. In: Proceedings Eighth Sardinia International Waste Management and Landfill Symposium. CISA, Cagliari., pp. 711-721 (2001).

4. $\quad$ van der Sloot H.A., Rietra R.R.J.J., Vroom R.C., Scharff H. and Woelders J.A., Similarities in the long term leaching behaviour of predominantly inorganic waste, MSWI bottom ash, degraded MSW and bioreactor residues. In: Proceedings Eighth Sardinia International Waste Management and Landfill Symposium. CISA, Cagliari., pp. 199-208 (2001).

5. GoldSim Technology Group, GoldSim modelling software. http://www.goldsim.com/. (2005).

6. Council of the European Union, Decision 2003/33/EC establishing criteria and procedures for the acceptance of waste at landfills pursuant to Article 16 of and Annex II to Directive 1999/31/EC. Official Journal of the European Communities, L11, 27-49 (2003).

7. Drury D., Hall D.H. and Dowle J., The development of LandSim 2.5. National Groundwater and Contaminated Land Centre report GW/03/09. Environment Agency, Bristol, (2003).

8. Council of the European Union, Council Decision of 19 December 2002 establishing criteria and procedures for the acceptance of waste at landfills pursuant to Article 16 of and Annex II to Directive 1999/31/EC. Official Journal of the European Communities, L 11, 27-49 (2002).

9. Council of the European Communities, Council Directive of 17 December 1979 on the protection of groundwater against pollution caused by certain dangerous substances (80/68/EEC). Official Journal of the European Communities L20, 26/01/1980, 43-48 (1980).

10. Council of the European Union, Council Directive 98/83/EC of 3 November 1998 on the quality of water intended for human consumption. Official Journal of the European Communities, L330, 32-54 (1998). 11. World Health Organisation, Guidelines for drinking-water quality. 2nd edition, Vol.2: Health criteria and other supporting information. WHO, Geneva. (1996).

12. Robinson H.D., A review of landfill leachate composition, Department of the Environment Report No. CWM 072/95. Environment Agency, Bristol, UK. (1995).

13. British Standards Institute, DD CEN/TS 14405: 2004. (2004).

14. European Environment Agency, Biodegradable municipal waste management in Europe - Parts 1,2 \& 3. Topic report No 15/2001, Copenhagen (2002).

15. Leikam K. and Stegmann R., Mechanical, biological pretreatment of residual municipal solid waste and the landfill behaviour of pretreated waste. In: Proceedings Eighth Sardinia International Waste Management and Landfill Symposium. CISA, Cagliari., pp. 463-474 (1997). 
16. Melloni R., Carlini N., Neri P., Pozzi V. and Bergonzoni M., Environmental and economic analysis of mechanical biological pre-treatment of MSW: an LCA approach. In: Proceedings Ninth Sardinia International Waste Management and Landfill Symposium. CISA, Cagliari. (2003).

17. Raninger B. and Nelles M., Mechanical-biological pretreatment prior to landfill disposal in Austria. In: Proceedings Sixthth Sardinia International Waste Management and Landfill Symposium. CISA, Cagliari., Vol.1, 429-436 (1997).

18. Robinson H.D., Knox K. and Bone B.D., Improved definition of leachate source term from landfills Phase 1: review of data from European landfills. Science Report P1-494/SR1, Environment Agency, Bristol (2004).

19. Binner E., The impact of mechanical-biological pretreatment on the landfill behaviour of solid wastes. In: The biological treatment of biodegradable waste - Technical aspects, Brussels (2002).

20. Scheelhaase T. and Bidlingmaier W., Effects of mechanical-biological pre-treatment on residual waste and landfilling. In: Proceedings Eighth Sardinia International Waste Management and Landfill Symposium. CISA, Cagliari., pp. 475-483 (1997).

21. Küehle-Weidemeier M., Landfill properties of mechanically and biologically treated municipal solid waste. In: Waste 2004 - Integrated Waste Management and Pollution Control: Policy and Practice, Research and Solutions, Stratford-upon-Avon, UK, pp. 725-734 (2004).

22. Leikam K. and Stegmann R., Influence of mechanical-biological pretreatment of municipal solid waste on landfill behaviour. Waste Management \& Research, 17, 424-429 (1999).

23. Bone B.D., Knox K., Picken A. and Robinson H.D., The effect of mechanical and biological pretreatment on landfill leachate quality. In: Proceedings Sardinia 2003, Ninth International Waste Management and Landfill Symposium, S. Margherita di Pula, Cagliari, Italy (2003).

24. Liwarska-Bizukojc E. and Ledakowicz S., Stoichiometry of the aerobic biodegradation of the organic fraction of municipal solid waste (MSW). Biodegradation, 14, 51-56 (2003).

25. European Commission, Refused derived fuel, current practice and perspectives. WRc Ref: CO5087-4. WRc, IFEU, Ecotec, Eunomia, Brussels, 229pp (2003).

26. Cozens P., EfW - an alternative vision. In: Biodegradable and residual waste management: 1st UK Conference and exhibition, Stentiford E.K.P.a.E.I. (ed.), Cal Recovery Europe Ltd, Harrogate, UK, pp. 464472 (2004).

27. Rand T., Haukohl J. and Marxen U., Municipal solid waste incineration: decision maker's guide. World Bank, Washington, DC (1999).

28. Environment Agency, Solid residues from municipal waste incinerators in England and Wales: a report on an investigation by the Environment Agency. Bristol, U.K., 72pp (2002).

29. Polettini A., Pomi R., Lo Mastro S. and Piacente E., Accelerated aging of incinerator bottom ash as a tool for landfill management optimisation. In: Proceedings Sardinia 2003, Ninth International Waste Management and Landfill Symposium, S. Margherita di Pula, Cagliari, Italy (2003).

30. Williams P.T., Emissions from solid waste management activities. In: Environmental and Health Impact of Solid Waste Management Activities, Hester R.E. and Harrison R.M. (eds.), Royal Society of Chemistry, pp. 141-170 (2002).

31. Hjelmar O., Disposal strategies for municipal solid waste incineration residues. Journal of Hazardous Materials, 47, 345-368 (1996).

32. Stegmann J.A., Schmeider J., Baetz B.W. and Murphy K.L., Lysimeter washing of MSW incinerator bottom ash. Waste Management and Research, 13, 149-156 (1995).

33. Johnson C.A., Kaeppeli M., Brandenberger S., Ulrich A. and Baumann W., Hydrological and geochemical factors affecting leachate composition in MSW incinerator bottom ash - Part II: The geochemistry of leachate from Landfill Lostorf, Switzerland. Journal of Contaminant Hydrology, 40, 239259 (1999).

34. Johnson C.A., Richner G.A., Vitvar T., Schittli N. and Eberhard M., Hydrological and geochemical factors affecting leachate composition in municipal solid waste incinerator bottom ash - Part I: The hydrology of Landfill Lostorf, Switzerland. Journal of Contaminant Hydrology, 33, 361-376 (1998). 
35. Shimaoka T., Miyawaki K., Hanashima M., Itoh I., Yoshida T. and Uchida T., Insolubilisation of Pb in fly ash using the exhaust gas from incineration plant. In: Proc. Sardinia 1999: Seventh International Waste Management and Landfill Symposium, Cagliari, Italy, pp. 565-572 (1999).

36. Lapa N., Santos O.J., Camacho S.L. and Circeo L.J., An ecotoxic risk assessment of residue materials produced by the plasma pyrolysis/vitrification (PP/V) process. Waste Management, 22, 335-342 (2002).

37. Thomas J., Compact Power. Bristol, UK (2004).

38. Environment Agency, Hydrogeological risk assessments for landfills and the derivation of groundwater control and trigger levels. LFTGN01, Bristol, (2003).

39. McLanaghan S., Delivering the Landfill Directive: the role of new and emerging technologies. Report to the Strategy Unit 0008/2002. Associates in Industrial Ecology, Penrith, UK., (2002).

40. Environment Agency, Waste pre-treatment: a review. R\&D Technical Report P1-344/TR. AEA Technology, Bristol, (2002). 


\section{FIGURE AND TABLE TITLE LIST}

Figure 1. The basic hydrogeological scenario for the basis of calculations.

Figure 2. Maximum receptor concentration versus length of management time for chloride.

Figure 3. Maximum receptor concentration versus length of management time for lead.

Figure 4. MBT system utilising a dirty MRF [38].

Table 1. Overview of waste processes investigated.

Table 2. Results of a preliminary benchmarking exercise for a current modern landfill.

Table 3. Results of benchmarking exercise for a current modern landfill using WAC leachate concentrations for hazardous waste going to a non-hazardous landfill.

Table 4. Typical anaerobic digestate heavy metal concentrations from MSW.

Table 5. Results of ash analysis for RDF. 
Figure 1.

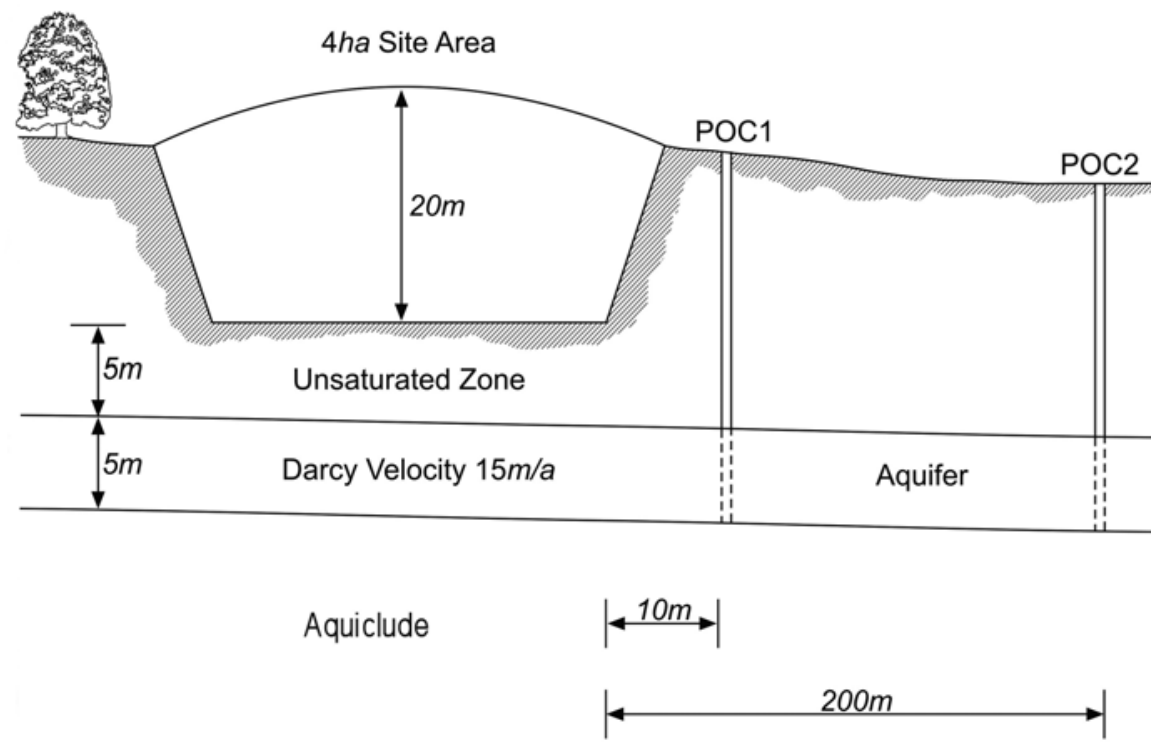


Figure 2.

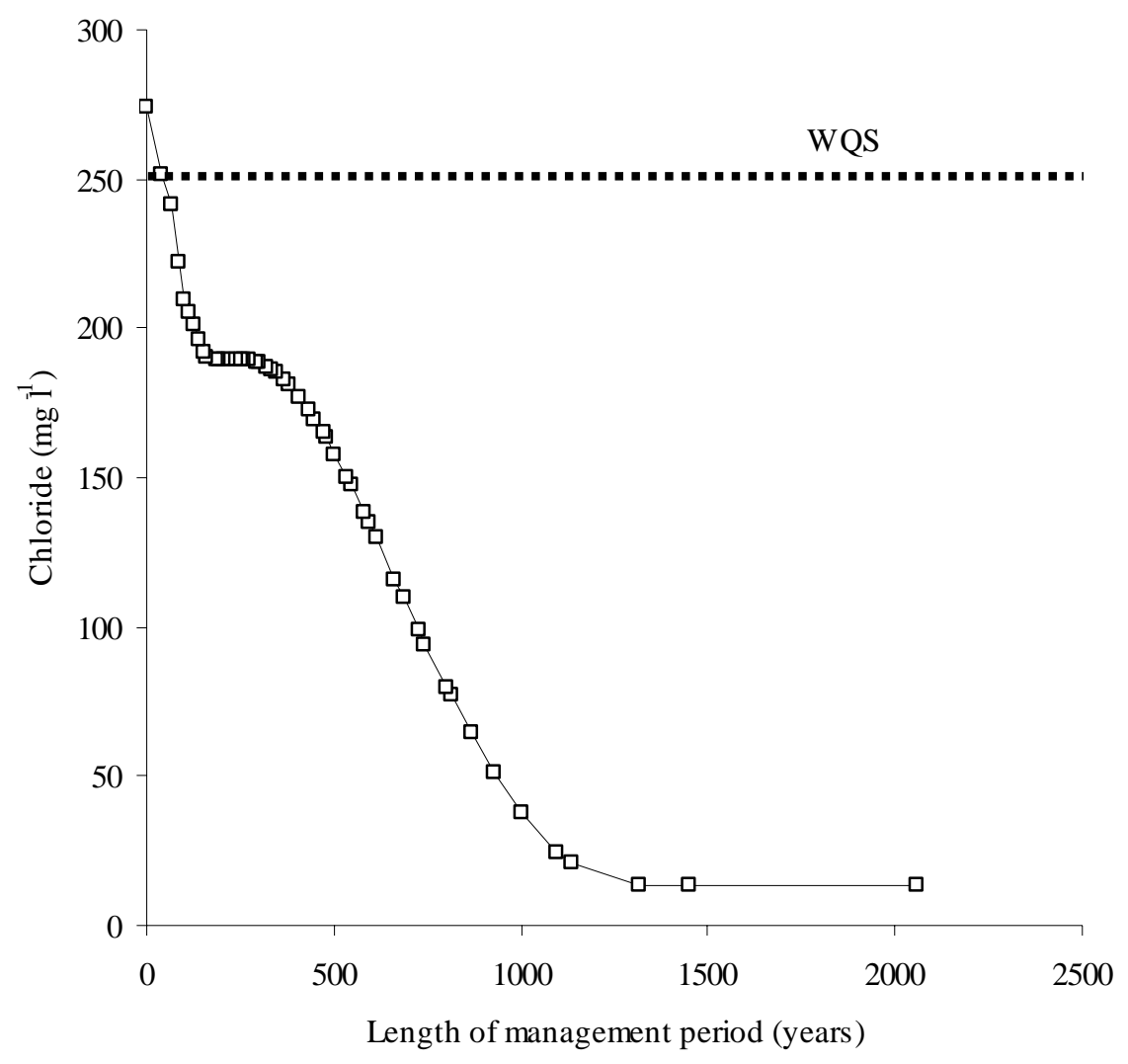


Figure 3.

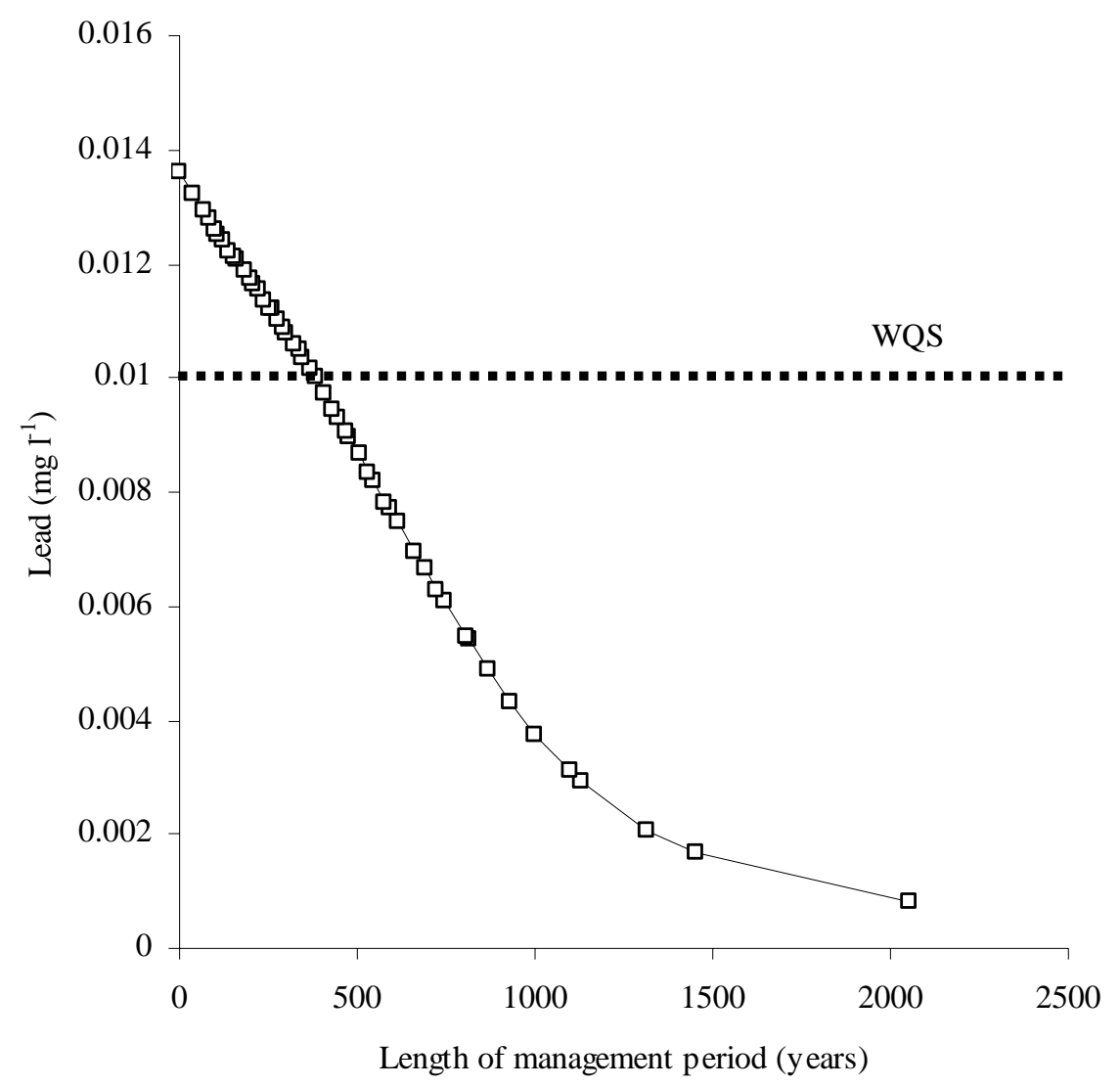


Figure 4. [39]

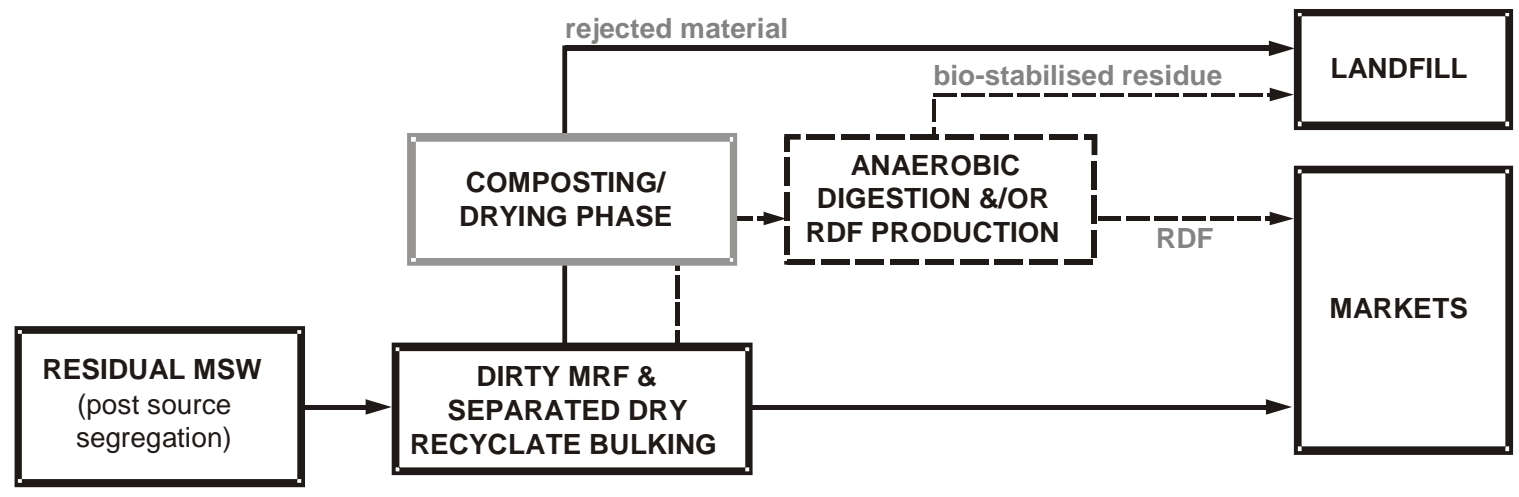

\section{DIRTY MRFS}

All dirty MRFs operate on the residual waste streams tonnage levels for a given population will - at present - be higher than for dry co-mingled recyclates.

This will probably result in dirty MRFs scaled for rural communities.

\section{Key}

denotes existing practice

- - denotes Landfill Directive compliant practice (which is illustrative of a form of Bio-Mechanical Treatment approach) 
Table 1. Overview of waste processes investigated.

\begin{tabular}{ll}
\hline Waste treatment process & Description \\
\hline MBT product & $\begin{array}{l}\text { Where mechanical biological treatment results in a product that should } \\
\text { have been useable but is unable to be sold or used and must be disposed of } \\
\text { to landfill. }\end{array}$ \\
MBT incorporating composting. \\
MBT/AD & MBT incorporating anaerobic digestion. \\
RDF co-incineration & $\begin{array}{l}\text { Refuse derived fuel produced by mechanical sorting only. } \\
\text { RDF dedicated }\end{array}$ \\
incineration & Refuse derived fuel produced by mechanical sorting only. \\
RDF - flock only & Where flock cannot be sold for incineration and is destined to landfill. \\
& \\
RDF/MBT & Where RDF results from a more sophisticated MBT process. \\
EfWMB & Energy from waste (mass burn). \\
EfWFB & Energy from waste (fluidised bed). \\
ATT & Advanced thermal treatment - pyrolysis/gasification. \\
\hline
\end{tabular}


Table 2. Results of a preliminary benchmarking exercise for a current modern landfill.

\begin{tabular}{|c|c|c|c|c|c|}
\hline Contaminant & $\begin{array}{c}\text { Point of } \\
\text { compliance } \\
\text { See note } 2 \\
\end{array}$ & $\begin{array}{c}\text { Initial } \\
\text { concentration } \\
\text { (see note } 3 \text { ) } \\
\end{array}$ & WQS & $\begin{array}{c}\text { Years to } \\
\text { achieve } \\
\text { equilibrium }\end{array}$ & Comments \\
\hline & & $\mathrm{mg} \mathrm{l}^{-1}$ & $\mathrm{mg} \mathrm{l}^{-1}$ & & \\
\hline Antimony (Sb) & 1 & & & & Not routinely measured \\
\hline Arsenic (As) & 1 & 0.013 & 0.01 & $<3$ & \\
\hline Barium (Ba) & 1 & & & & Not routinely measured \\
\hline Cadmium (Cd) & US & 0.01 & 0.005 & $<3$ & See note 1 \\
\hline Chromium (Cr) & 1 & 0.18 & 0.050 & $<3$ & \\
\hline Copper $(\mathrm{Cu})$ & 1 & 0.1 & 0.05 & $<3$ & \\
\hline Mercury (Hg) & US & 0.00009 & 0.001 & $<3$ & See note 1 \\
\hline Lead $(\mathrm{Pb})$ & 1 & 0.17 & 0.01 & 400 & \\
\hline $\begin{array}{l}\text { Molybdenum } \\
\text { (Mo) }\end{array}$ & 1 & & & & Not routinely measured \\
\hline Nickel (Ni) & 1 & 0.24 & 0.02 & $<3$ & \\
\hline Zinc (Zn) & 1 & 5.09 & 0.1 & $1100-1300$ & $\begin{array}{l}\text { Only applicable to the } \\
\text { acetogenic phase of the } \\
\text { landfill, therefore this is } \\
\text { not a real issue. }\end{array}$ \\
\hline Selenium (Se) & 1 & & & & Not routinely measured \\
\hline Fluoride $(\mathrm{F})$ & 2 & & & & Not routinely measured \\
\hline Sulphate $\left(\mathrm{SO}_{4}\right)$ & 2 & 263 & 250 & $<3$ & \\
\hline Chloride $(\mathrm{Cl})$ & 2 & 1466 & 250 & $40-60$ & \\
\hline $\begin{array}{l}\text { Ammoniacal } \\
\text { Nitrogen }\left(\mathrm{NH}_{4}\right)\end{array}$ & 1 & 495 & 0.5 & $<3$ & $\begin{array}{l}\text { Assumed to biodegrade } \\
\text { with a half life of } 6 \text { yrs }\end{array}$ \\
\hline
\end{tabular}

Note 1 - The water quality standard for List I substances has been used in the modelling. If the minimum reporting values [38], are used for these two species then the time period runs to in excess of 2000 years).

Note 2 - The point of compliance (POC) - US is the base of the unsaturated zone, point 1 is groundwater at the boundary of the site, and point 2 is groundwater at a distance of $200 \mathrm{~m}$ downstream.

Note 3 - Based on the mean values from the LandSim 2 defaults for non-List 1 substances. 
Table 3. Results of benchmarking exercise for a current modern landfill using WAC leachate concentrations for hazardous waste going to a non-hazardous landfill.

\begin{tabular}{|c|c|c|c|c|c|}
\hline Contaminant & $\begin{array}{c}\text { Point of } \\
\text { compliance } \\
\text { See note } 1 \\
\end{array}$ & $\begin{array}{c}\text { Initial } \\
\text { concentration }\end{array}$ & WQS & $\begin{array}{c}\text { Years to } \\
\text { achieve } \\
\text { equilibrium }\end{array}$ & Comments \\
\hline & & $\mathrm{mg} \mathrm{l}^{-1}$ & $\mathrm{mg} \mathrm{l}^{-1}$ & & \\
\hline Antimony (Sb) & 1 & 0.15 & 0.005 & $>2000$ & Not routinely measured \\
\hline Arsenic (As) & 1 & 0.3 & 0.01 & $>2000$ & \\
\hline Barium (Ba) & 1 & 20 & 0.7 & $>2000$ & Not routinely measured \\
\hline Cadmium (Cd) & US & 0.3 & 0.005 & $>2000$ & \\
\hline Chromium (Cr) & 1 & 2.5 & 0.05 & $1100-1300$ & \\
\hline Copper $(\mathrm{Cu})$ & 1 & 30 & 0.05 & $>2000$ & \\
\hline Mercury (Hg) & US & 0.03 & 0.001 & $>2000$ & \\
\hline Lead $(\mathrm{Pb})$ & 1 & 3 & 0.01 & $>2000$ & \\
\hline $\begin{array}{l}\text { Molybdenum } \\
\text { (Mo) }\end{array}$ & 1 & 3.5 & 0.07 & $1300-1450$ & Not routinely measured \\
\hline Nickel (Ni) & 1 & 3 & 0.02 & $1500-2000$ & \\
\hline Zinc $(\mathrm{Zn})$ & 1 & 15 & 0.1 & $>2000$ & \\
\hline Selenium (Se) & 1 & 0.2 & 0.01 & $930-1000$ & Not routinely measured \\
\hline Fluoride (F) & 2 & 40 & 1.5 & $1450-2000$ & Not routinely measured \\
\hline Sulphate $\left(\mathrm{SO}_{4}\right)$ & 2 & 7000 & 250 & $1300-1450$ & \\
\hline Chloride $(\mathrm{Cl})$ & 2 & 8500 & 250 & $930-1000$ & \\
\hline $\begin{array}{l}\text { Ammoniacal } \\
\text { Nitrogen }\left(\mathrm{NH}_{4}\right)\end{array}$ & 1 & 2000 & 0.39 & 1100 & $\begin{array}{l}\text { Assumed to biodegrade with } \\
\text { a half life of } 6 \text { yrs }\end{array}$ \\
\hline
\end{tabular}

Note 1 - US is the base of the unsaturated zone, point 1 is groundwater at the boundary of the site, and point 2 is groundwater at a distance of $200 \mathrm{~m}$ downstream. 
Table 4. Typical anaerobic digestate heavy metal concentrations from MSW [40].

\begin{tabular}{|c|c|c|c|}
\hline Parameter & 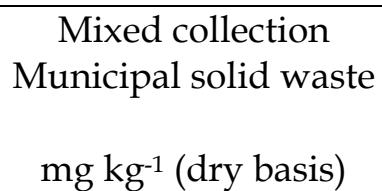 & $\begin{array}{c}\text { Separated } \\
\text { vegetable, fruit } \\
\text { and garden waste } \\
\text { mg kg-1 (dry basis) }^{-1} \text { (dry }\end{array}$ & $\begin{array}{l}\text { Separated vegetable, fruit } \\
\text { and garden waste and } \\
\text { paper } \\
\text { mg kg-1 (dry basis) }^{-1}\end{array}$ \\
\hline Cadmium & 2 & 2 & 1 \\
\hline Zinc & 1020 & 138 & 85 \\
\hline Copper & 101 & 20 & 14 \\
\hline Lead & 522 & 67 & 61 \\
\hline Nickel & 42 & 25 & 7 \\
\hline
\end{tabular}


Table 5. Results of ash analysis for RDF (EUS Laboratories Ltd, 22nd Feb. 2002).

\begin{tabular}{lcc}
\hline Element & Solid $\mathrm{mg} \mathrm{kg}^{-1}$ & Leachate $\mu \mathrm{gg}^{-1}$ \\
\hline Total organic carbon & 455 & $\mathrm{Na}$ \\
Total hydrocarbon & 76 & $\mathrm{na}$ \\
Cadmium & 36 & 0.8 \\
Thallium & $<0.5$ & 1.3 \\
Mercury & $<0.1$ & $<0.1$ \\
Lead & 8 & 8 \\
Chromium & 650 & 9 \\
Copper & 720 & 143 \\
Manganese & 830 & 12 \\
Nickel & 120 & 4 \\
Arsenic & 23 & 12 \\
Antimony & 48 & 4 \\
Cobalt & 12 & 8 \\
Vanadium & 16 & 9 \\
Tin & 870 & 10 \\
Dioxin / furan & $22.5 \mathrm{ng} \mathrm{kg-1}$ & $0.0063 \mathrm{ng} \mathrm{l}^{-1}$ \\
\hline
\end{tabular}

